\title{
Perinatal risiko hos yngre søsken av premature
} Kvinner som har født et prematurt barn, gjør det ofte igjen. Selv når neste
fødsel er til termin, er dødeligheten hos barnet økt.

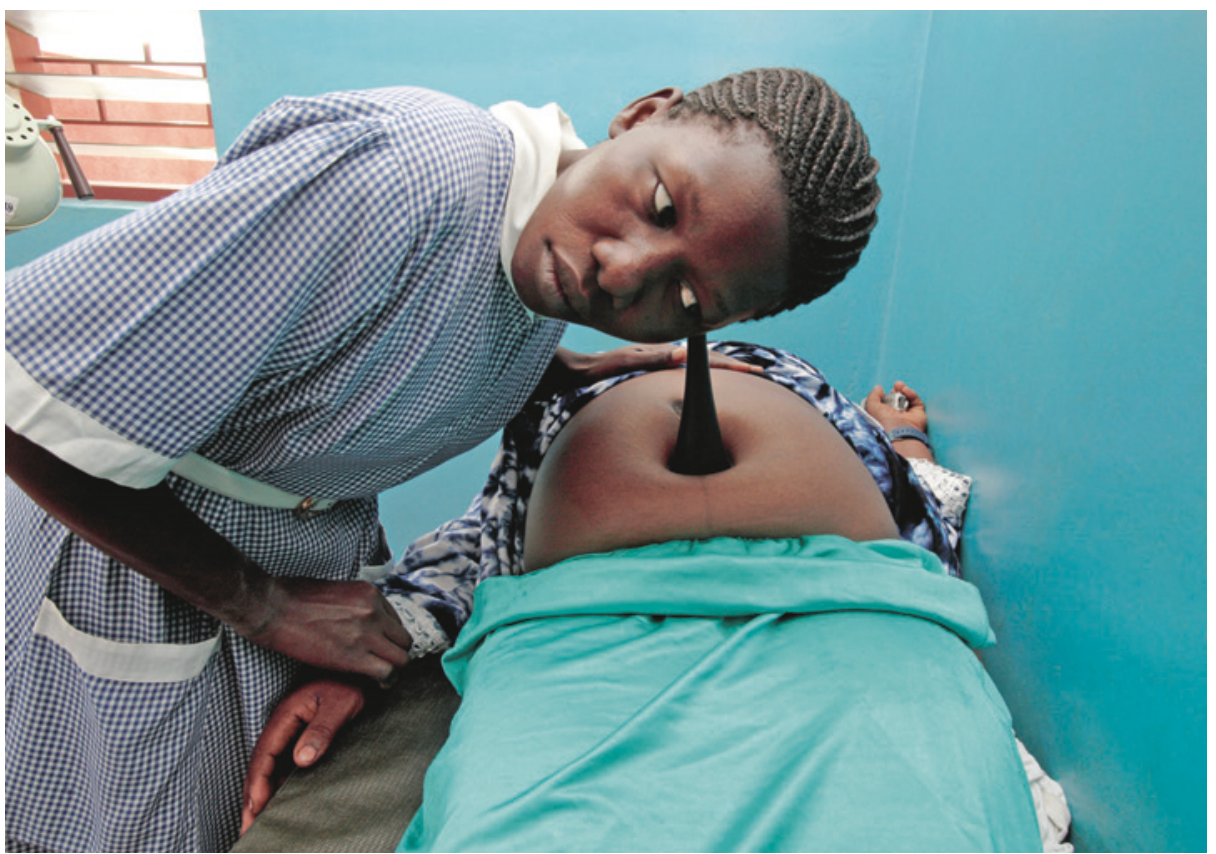

Illustrasjonsfoto Science Photo Library/NTB scanpix

Dette viser en prospektiv studie ved et sykehus i Tanzania. 18176 kvinner som fødte i årene 2000-08 ble fulgt frem til 2010 for å se hvordan det gikk i deres påfølgende svangerskap (1). I studieperioden fikk kvinnene totalt 3867 nye barn, hvorav 578 hadde eldre søsken født før termin < 37 fullgåtte svangerskapsuker). Av disse ble $17 \%$ selv født for tidlig. Dette var 2,7 ganger $(95 \% \mathrm{KI}$ 2,1-3,4) hyppigere enn blant de barna som hadde eldre søsken født til termin.

Også andre forhold ved forrige svangerskap predikerte fødsel før termin i neste: preeklampsi (relativ risiko (RR) 2,5, $95 \%$ KI 1,7-3,7), perinatal død (RR 2,5, 95\% KI 1,9-3,5) og lav fødselsvekt (RR 2,9, 95\% $\mathrm{KI} 2,3-3,6)$. Blant barna som selv var født til termin, men som hadde eldre søsken som var født for tidlig, var det en perinatal dødelighet på hele $10 \%$, tilsvarende 5,9 ganger $195 \%$ $\mathrm{KI} 4,1-8,8) ø \mathrm{kt}$ risiko sammenliknet med dem som hadde terminfødte eldre søsken.
- Studien bekrefter budskapet fra WHO om at tidligere fødsel før termin er en sterk prediktor for at dette skal skje neste gang også. I tillegg er det en risikofaktor for perinatal død hos senere barn, også når de ikke selv er premature, sier Micheal J. Mahande, førsteforfatter av studien og stipendiat ved Institutt for Global helse og samfunnsmedisin, Universitetet i Bergen. Mahande mener dette kan forklares med at i Tanzania er de kvinnene som føder for tidlig, i stor grad de som har fått minst oppfølging i svangerskapet, i motsetning til hva man ser i f.eks. Norge.

\section{Kristoffer Brodwall}

kristoffer.brodwall@gmail.com

Institutt for global helse og samfunnsmedisin Universitetet i Bergen

\section{Litteratur}

1. Mahande MJ, Daltveit AK, Obure J et al. Recurrence of preterm birth and perinatal mortality in northern Tanzania: registry-based cohort study. Trop Med Int Health 2013. E-publisert 13.4.2013.

\section{Stress i arbeidet gir ikke mer kreft}

\author{
Det er ingen sammenheng mellom \\ jobbstress og total kreftrisiko eller \\ risiko for kreft i tykk- og endetarm, \\ lunge, bryst og prostata. Dette \\ viser en ny metaanalyse.
}

Stress i arbeidslivet er forbundet med flere alvorlige helsetilstander, bl.a. hjertesykdom og depresjon. I studier av kreftrisikoen ved jobbstress har det ikke vært like konsistente funn. Nå har en internasjonal forskergruppe utført en metaanalyse for å undersøke om arbeidsrelatert stress kan påvirke den totale kreftrisikoen og risikoen for enkelte krefttyper (1).

I analysen inngikk data fra mer enn 116000 menn og kvinner uten kreft fra 12 europeiske kohortstudier. 5765 utviklet kreft etter 12 års oppfølging (median). Jobbstress var ikke var assosiert med totalrisiko for kreft (hasardratio (HR) 0,97; $95 \%$ KI 0,90-1,04) etter justering for bl.a. kjønn, alder og livsstilsfaktorer. Det var heller ingen sammenheng mellom jobbstress og kreft i tykk- og endetarm (HR 1,16 ; $95 \%$ KI 0,90-1,48), lunge (HR 1,17; $95 \%$ KI $0,88-1,54)$, bryst (HR 0,97; $95 \%$ KI $0,82-1,14$ ) eller prostata (HR 0,86 ; $95 \%$ KI 0,68-1,09).

- Dette er en stor og spennende metaanalyse, sier professor Geir Arild Espnes, som er leder for Senter for helsefremmende forskning ved Norges teknisk-naturvitenskapelige universitet. - Det er liten grunn til å anta at jobbstress er en viktig risikofaktor for de fire vanligste kreftformene man her har undersøkt. Dette er nok ikke noe oppsiktsvekkende resultat og det er svakheter i studiens metode, spesielt når det gjelder harmonisering av resultatene fra studiene som inngår. Studien er likevel viktig på veien mot å forstå psykologiske påvirkninger, slik som stress, som potensielle karsinogener, sier Espnes.

\section{Trine B. Haugen}

trine.b.haugen@hioa.no

Tidsskriftet

\section{Litteratur}

1. Heikkilä K, Nyberg ST, Theorell T et al. Work stress and risk of cancer: meta-analysis of 5700 incident cancer events in 116,000 European men and women. BMJ 2013; 346: f165. 